\title{
ПРЕДИСЛОВИЕ К РОССИЙСКОМУ ИЗДАНИЮ
}

《нига австрийского историка Арнольда Зуппана в оригинале Кназывается «1000 лет соседства. “Чехи” и “австрийцы” в исторической перспективе». Имена народов-соседей, взятые в кавычки, должны привлечь внимание читателя к условности названий современных наций, каждая из которых прошла долгий путь к обретению современных, признаваемых на международном уровне нерушимыми государственных границ, вобрала в свои ряды представителей разных этносов, из которых в горниле модернизационных процессов «долгого XIX века» были «выплавлены», «выкованы» современные национальные сообщества. И австрийцы, и чехи - нации древние в обосновании исторической преемственности, и молодые с точки зрения обретения современных форм государственности.

Века соседства знали периоды соперничества, сотрудничества, вражды, взаимного приспособления, поиска общего языка. Австрийские немцы, как до 1918 г. правильнее называть «австрийцев», не один век соседствовали с чехами, создавшими к XIII в. одно из мощнейших государств Европы, в рамках Священной Римской империи; в XVI в. они на четыре столетия оказались объединены в составе владений Австрийского дома, как в то время называли Габсбургскую династию; в 1918 г. образовались Немецкая Австрия и Чехословакия, в 1920 г. их парламенты приняли конституции, провозгласившие эти государства демократическими республиками, независимое существование которых оборвалось почти одновременно в 1938 г. - вслед за аншлюсом Австрии последовал Мюнхенский сговор, расчленение Чехословакии и создание протектората Богемии и Моравии в марте 1939 г.; возродились в 1945 г., 
чтобы прожить без малого полвека по разные стороны «железного занавеса», наконец, в начале XXI в. стали соседями в границах Европейского союза.

Изучение и описание истории соседства двух народов с тесно переплетенными судьбами требует от историка и широкой эрудиции, в том числе историографической, и глубины проникновения в суть механизмов взаимодействий и конфликтов на продолжительном временном отрезке. Ученый, берущийся за столь масштабную задачу, встает перед вызовами современной глобальной истории, вписывающей локальное в универсальное и находящей параллели между явлениями одного порядка в разных концах глобального мира. Этот методологический вызов принял Арнольд Зуппан - авторитетный австрийский историк, действительный член Австрийской академии наук, в сентябре 2021 г. избранный ее вице-президентом, эмерит-профессор Венского университета, ведущий специалист по ключевым проблемам истории Центральной и Восточной Европы XIX-XX вв., один из инициаторов и ответственных редакторов фундаментального многотомного издания «Внешнеполитические документы Австрийской республики. 1918-1938» ${ }^{1}$, автор книг «Народности Австрии. Тенденции социального развития в ХХ в.» (1983), «Югославия и Австрия 1918-1938. Двусторонняя внешняя политика в мировом контексте» $(1996)^{2}$. Российскому читателю знакомы статьи Арнольда Зуппана ${ }^{3}$, в том числе «Конфликт, война и геноцид в Центрально-Восточной и Юго-Восточной Европе. 1938-1948» ${ }^{4}$, в которой автор кратко изложил основные тезисы фундаментального трехтомника «Гитлер - Бенеш - Тито» ${ }^{5}$. Возможно, исследуя полные драматизма страницы в новейшей истории соседствующих в истории и на географической карте австрийцев и чехов, ученый задумал совершить экскурс в глубь веков, понять причины взаимного притяжения, обогащения культур, отторжения и открытого неприятия, примирения и поиска общего языка.

Плодом раздумий автора стала эта книга: 12 глав, посвященных ключевым, поворотным, судьбоносным моментам истории

${ }^{1}$ Koch et al. 1993-2016.

${ }^{2}$ Suppan 1983; Suppan A. 1996

3 Зуппан / Штепплер 2000; Зуппан 2016а.

${ }^{4}$ Зуппан $2016 \mathrm{~b}$

${ }^{5}$ Suppan 2014. 
народов, населяющих современные Австрию и Чехию с конца X в. до начала XXI в. Синтез тысячелетней истории дополнен богатой библиографией и историческими картами. В русском переводе книге предпослан подзаголовок «взгляд из Австрии», потому что при последовательном стремлении к объективности автор остается австрийским историком, осмысляющим прежде всего свое национальное прошлое. В переводе на русский язык сознательно сохранена амбивалентность имен собственных, топонимов и этнонимов. В первую очередь это относится к дихотомиям «Чехия»/ «Богемия», «чешский»/«богемский». В книге сохранено традиционное для российской историографии употребление термина «Чехия» как для королевства, так и для его главной составной части (земли), термин же «Богемия» появляется в австро-немецком контексте, подчеркивая и то, что «Богемия» была важнейшей составной частью Священной Римской империи и позднее владений Австрийского дома. По этой же логике немецкое население Чешских земель - «богемские», а не «чешские» немцы. В целом в книге используется общепринятая в русском языке славянская топонимика, однако вслед за логикой немецкого авторского текста для ряда городов и населенных пунктов предусмотрено двойное написание через косую черту, напоминающее как об этнически смешанном населении, так и о многоуровневом административно-государственном подчинении.

Книга адресована профессиональному научному сообществу и широкому кругу читателей, интересующихся историей, может служить пособием по общим и специальным курсам Новой и новейшей истории. С автором можно не соглашаться, можно искать ответы на вопросы, которые он обошел вниманием, размышлять о структуре и формах изложения истории народов-соседей, об отмеченной им живучести стереотипов массового сознания и исторических нарративов, о мужестве, необходимом для признания ошибок прошлого и поиска общего языка при строительстве мира без вражды и ненависти. Автор честен с читателем, надеемся, что российский читатель ответит автору искренним интересом.

Работа над переводом, его редактирование, подготовка рукописи в печать потребовали объединенных усилий автора, переводчика и ответственных редакторов, консультантов и рецензентов. Выражаем благодарность ведущему научному сотруднику Института славяноведения РАН, кандидату исторических наук Георгию 
Павловичу Мельникову за неоценимую помощь в работе над переводом, критические замечания и указание на допущенные ошибки и неточности. Мы признательны Институту славяноведения РАН за поддержку проекта, Австрийской академии наук и Институту истории Габсбургов и балканских исследований - за его финансирование.

Н.Н. Станков, О.В. Хаванова 